\title{
Application method of water repellent products and its influence on the suction process on the facade of ceramic brick
}

\author{
Método de aplicación de los productos hidrofugantes y su influencia en la succión del ladrillo cerámico \\ cara vista
}

Jesus Angel Coronado Marín

Pontificia Universidad Católica de Ecuador, Sede Ibarra

Carrera de Arquitectura

jcoronado71@gmail.com

Alfonso Garcia Santos

Universidad Politécnica de Madrid. Escuela Técnica Superior de Arquitectura. Departamento de Construcción y Tecnología Arquitectónicas.

alfonso.garciasantos@upm.es

\author{
Manuscript Code: 0474 \\ Date of reception/acceptation: 01aug2014/01dec2014
}

\section{Resumen}

Se analiza la variación de peso, tasa de absorción y de nivel de agua superficial que sufre el soporte cerámico protegido por la incorporación de un tratamiento con productos hidrofugantes. Los productos hidrofugantes se seleccionan en función de su composición química en seis tipos, clasificados en monocomponente y bicomponente. La hidrofugación del soporte cerámico se realiza mediante dos procedimientos: pincel e inmersión, con cada uno de los hidrofugantes seleccionados. Se realiza la prueba de succión obteniendo datos cada uno, dos, cinco, diez, quince, veinte, veinticinco y treinta minutos. Se observa que todos los hidrofugantes aplicados superficialmente a un material cerámico poroso, reducen los parámetros de variación de peso, tasa de absorción y nivel de agua superficial respecto del material base sin hidrofugar, independientemente del método utilizado para su aplicación (pincel o inmersión).

La hidrofugación mediante el producto de componente silano, aplicado mediante pincel, produce los resultados más óptimos respecto de los parámetros de variación de peso y tasa de absorción, siendo los siliconatos aplicados mediante pincel y los silanos/siloxanos por inmersión los que obtienen resultados más óptimos en la medición del nivel de agua superficial.

Palabras claves: Cerámica porosa, succión, tasa de absorción, productos hidrofugantes, nivel de agua.

\section{Introduction}

The most frequent failures are produced due to the humidity originated from the rain water that infiltrates through the roof and façade, as well for water penetration from the land surrounding the basement wall and ground floors through ascending absorption due to the phenomenon known as capillarity (Chavez \& Alvarez, 2005).

At the restoration worksites of the historic sites is frequently to use consolidants or water repellent products for the protection of façades made in stone or ceramic. The water repellent products have as goal the objective of protecting the stone/and or ceramic of the accessing of the water to its interior and the aggressive air pollution. Waterproofing is a treatment that doesn't generates a membrane and drastically reduces water

\begin{abstract}
The variation of weight, absorption ratio and surface water level undergone by the ceramic support protected by the incorporation of a treatment with water repellent products is analyzed. The water repellent products are selected based on their chemical composition in six types, classified in monocomponent and bicomponent. The waterproofing of the ceramic support is carried out through two processes: brush and immersion, with each one of the water repellents. The suction test is carried out, obtaining data each one, two, five, ten, fifteen, twenty, twenty-five and thirty minutes. All the water repellent applied superficially to a porous ceramic material show a reduction in the variation of weight, absorption ratio and surface water level parameters with regards to the base material without waterproofing, regardkes if the method used for its application (brush or immersion). Waterproofing through the silanes component product applied through brush causes the optimal results with regards to the variation of weight and absorption ratio parameters, being the siliconates applied trhough brush and the silanes/siloxanes through immersion those obtaining the optimal results in the surface water level measurement.
\end{abstract}

Keywords: Porous ceramic, suction, rate of absorption, water repellent products, water level.

suction, without plugin the pores, thereby, without modifying significantly the permeability of the foundation to water steam (Fort, 2007).

In previous works about the suction of the Porous Ceramics, Coronado et all (2013), analyze the alterations produced in the porous ceramic façade of extruded manufacturing, when treated superficially with water repellent products, studying the suction of the porous ceramic, quantifying the alteration degree that produces each water repellent product on the surface of the porous ceramic, through images obtained with the Scanning electron microscope (SEM).

In other research, is studied the variation of the parameters of the initial absorption rate and the surface water level that suffers the façade of the porous ceramic when is superficially 
treated with water repellent products, identifying the waterproofing product of siliconate composition as recommended for waterproofing the ceramic, manufactured either manually, pressed or extruded (Coronado et all, 2013).

The choice of the method for the application of the waterproofing product is done in such way to obtain the best penetrability in the material, for the product to perform optimally (Young et all, 1999). This penetrability is influenced, aside from the characteristics of the water repellent product, by the method of application of the product, the type of solvent, the time of contact, the relative humidity, the pressure and temperature under which the application was made (Doehne \& Price, 2010).

There are different methodologies for the application of the product that varies according to the size of the objects, which can be treated at the laboratory or in big worksites or buildings that require an "in situ" treatment. One of the most used methods at the ceramic factories is the treatment through complete immersion by pressure and at room temperature; the brush is commonly used at the laboratory.

This research studies the influence of the application methods of the water repellent product, analyzing the weight variation, the initial absorption rate, and the level of water absorbed that suffers the porous ceramic. Each chosen ceramic is waterproofed over its test facades, one through brush and other by immersion. The methodology applied is based on the standard UNE-EN 772-11:2001, obtaining comparatives results for the choice of the water repellent product and the right application method.

Materials

\section{Porous Ceramic}

A façade of porous ceramic of "extruded" manufacturing has been analyzed. The complete bricks with measures of $240 \times 114 \times 48 \mathrm{~mm}$ were taken as ceramics. The characteristics of the chosen porous ceramics are: Water Absorption (\%): $\leq 15$. Suction (g/cm2xmin): $\leq 0,1$. Hole Percentage (\%): $\leq 45$. Completed Surface: Smooth.

\section{Water repellent products}

The water repellent products are an impregnation, theorically colorless, that penetrates through the porosity of the material on which it's applied. The adherence between an impregnation and the ceramic it's due to various factors but fundamentally the difference of surface tensions existing between both materials. The composition of the water repellent products is based on the use of polymeric materials that have less surface tension than the rest of the materials used in construction thus guaranteeing its union. (Garcia, 2001)

The water repellent products are structured in two big groups: organic and organic-silicic (Fort, 2007). The studied are organicsilicic as today are the most used for the application over facades of porous ceramic materials, thus classified in: monocomoponent and bicomponent. Monocomponent: they are obtained as a result from an alkyltrichlorosilane, being the next: Silicones, Silanes, Siloxanes: Oligomeric Alkyl koxy silanes and Polymeric Alkyl koxy silanes, Resins. Bicomponent: they are obtained from the mix of the mono-components. The selection of the water repellent products is done in function of their composition (Coronado and Garcia Santos, 2011).

\section{Methodology}

The methodology used is based on the standard UNE-EN 77211:2001. All the experiments are done at the laboratory for construction materials in the "Higher Technical School of Architecture of Madrid" where we meet temperature conditions of $20^{\circ} \mathrm{C}$ and a relative humidity of $35 \%$.

For the realization of the experiment the next equipment should be ready: a bucket of $50 \mathrm{~mm}$ depth, a support to keep the ceramic on the bucket, timer, a scale to weigh the ceramics with a precision of $0,01 \mathrm{~g}$, laboratory table, Olympus photo camera 400 digital, 4.0 megapixel

Of each model of porous ceramics façade selected will be chosen seven samples. Each sample its waterproofed on its test façade through brush until saturation of the support and the other facade through immersion. The waterproofing process is done through a brush until the saturation of the support, according to the indications of the manufacturers (Wacker-chemie Gmbh, 1973).

The waterproofed through immersion is done placing the ceramic in a container full of the water repellent product to a certain level, leaving it there a minute. Metal cylinders are inserted on which the ceramic rests when inserted in the container, so that most of the surface of the façade which is required to be waterproofed, is in direct contact with the water repellent product. The ceramic is waterproofed according to Figure 1.

\begin{tabular}{|c|c|c|c|c|}
\hline Classification & $\begin{array}{l}\text { Water } \\
\text { repellent }\end{array}$ & Component & Solution & $\begin{array}{l}\text { Density } \\
\text { (kg/liter) }\end{array}$ \\
\hline \multirow{5}{*}{$\begin{array}{l}\text { Mono } \\
\text { component }\end{array}$} & H1 & Silicones & $\begin{array}{l}\text { Liquid } \\
\text { water }\end{array}$ & 1,001 \\
\hline & $\mathrm{H} 2$ & Silanes & $\begin{array}{l}\text { Solvent } \\
\text { (xylene) }\end{array}$ & 0,8 \\
\hline & H3 & $\begin{array}{l}\text { Oligomeric } \\
\text { Siloxanes }\end{array}$ & $\begin{array}{l}\text { Solvent } \\
\text { (white } \\
\text { sprit*) }^{*}\end{array}$ & 0,9 \\
\hline & $\mathrm{H} 4$ & $\begin{array}{l}\text { Polimeric } \\
\text { Siloxanes }\end{array}$ & $\begin{array}{l}\text { Solvent } \\
\text { (white } \\
\text { spirit*) }\end{array}$ & 0,83 \\
\hline & H5 & $\begin{array}{l}\text { Fluoridated } \\
\text { resin }\end{array}$ & $\begin{array}{l}\text { Liquid } \\
\text { water }\end{array}$ & $0,95-1,00$ \\
\hline $\begin{array}{l}\text { Bi } \\
\text { component }\end{array}$ & $\mathrm{H} 6$ & $\begin{array}{l}\text { Silanes / } \\
\text { Siloxanes }\end{array}$ & $\begin{array}{l}\text { Liquid } \\
\text { water }\end{array}$ & 1 \\
\hline
\end{tabular}


The classification of the ceramic is done in each of its faces with the water repellent product code finished with the letter $\mathbf{B}$, if it is waterproofed with brush, or I if the waterproofed is done through immersion. Each ceramic will be doubly waterproofed on its facades. For example, a ceramic will have a facade classified as H1B (Waterproofed with $\mathrm{H} 1$ Siliconates through brush (B) and the other as $\mathrm{H} 1 \mathrm{l}$ (Waterproofed with $\mathrm{H} 1$ siliconates through immersion (I)). The ceramic classified as $\mathrm{HO}$ is a ceramic without waterproofing.

The drying time of the Waterproofed samples is 24 hours (this is the recommended time for the manufacturers to dry the water repellent agent completely), doing some proves of suction between 24 hours and the 72 hours after the waterproofing process. Once waterproofed the ceramic, its facade is submerged in the bucket of water previously filled with water up to the level indicated (this level is obtained by adding to the reservoir $300 \mathrm{~g}$ of water), according to the figure 2 .
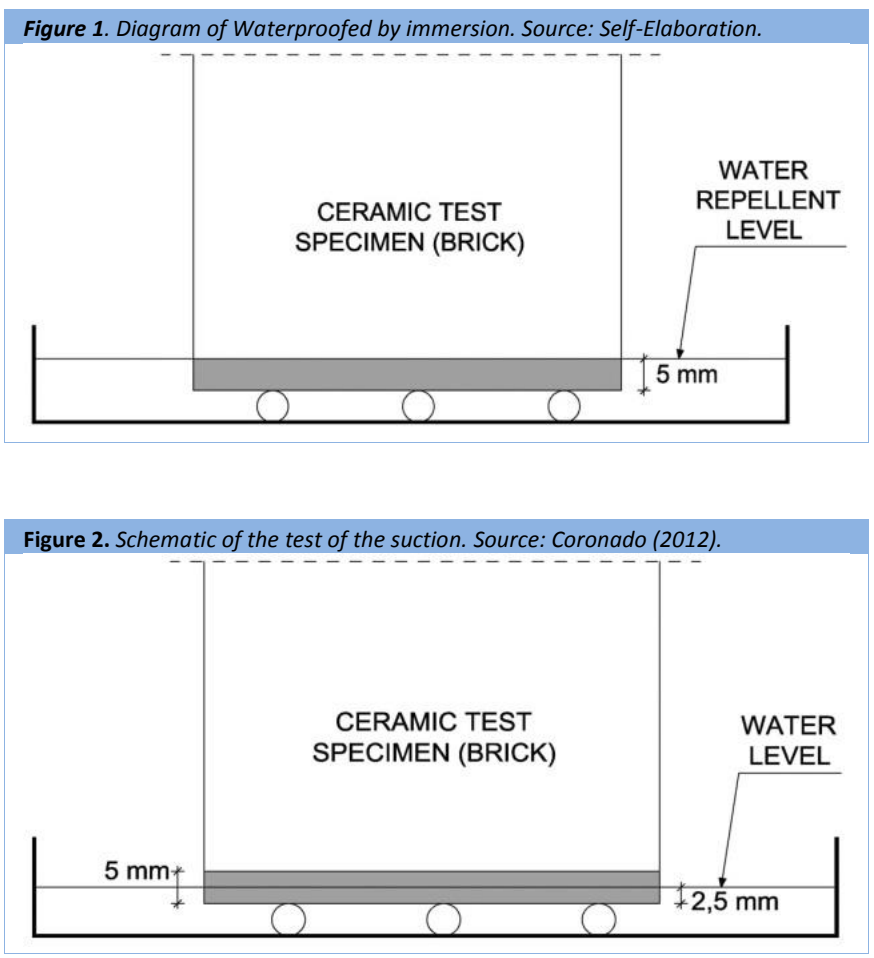

The ceramic is submerged in the bucket 1 minute; it is weighed and placed on the laboratory table where a picture is taken of the edge face. It's submerged again in the bucket and the process is repeated for the $2,5,10,15,20,25$ and 30 minutes (Coronado, 2012).

To obtain the pictures place the camera on the laboratory table, in which, at its base is the ceramics at a distance of $40 \mathrm{~cm}$ from the façade side up to the camera lens (Coronado, 2012). It is placed a scale to measure the increase in water level on the surface of the ceramic. Is obtained for all the indicated times, the total weight of the ceramics in ambient temperature plus the weight of the sucked water. Therefore, it is estimated the increase in weight (per thousand) that the ceramics experiences as a function of time. Its rate of absorption is estimated according to the standard UNE-EN 772-11:2001 using the equation (1).

$$
\mathrm{C}=(\mathrm{Mi}-\mathrm{Ma}) /(\text { As } \mathrm{xt})
$$

Where $\mathrm{C}$ is the rate of absorber. $\mathrm{Mi}$ is the mass of ceramics after immersion. $\mathrm{Ma}$ is the mass of the ceramic in room temperature. As is the gross surface of the submerged face and $t$ is the time.

The increase of water level on the ceramic surface is done by analyzing the picture obtained in the computer program. The picture is uploaded in this program; the scale is transformed into digital format to be able to place it in the area where the ceramic suction occurs.

The suction process in the ceramic, of both: the water repellent product and water, is produced none equally (as represented in the figure 3 ), thus the material is porous and therefore not homogeneous. To get the water level is necessary to mark the highest level left on the surface of the ceramic moving it to the scale to get its value (Coronado Martín 2012). It is obtained from the data of the water level, the percentage of variation existing between the measurements of the levels in consecutive times.

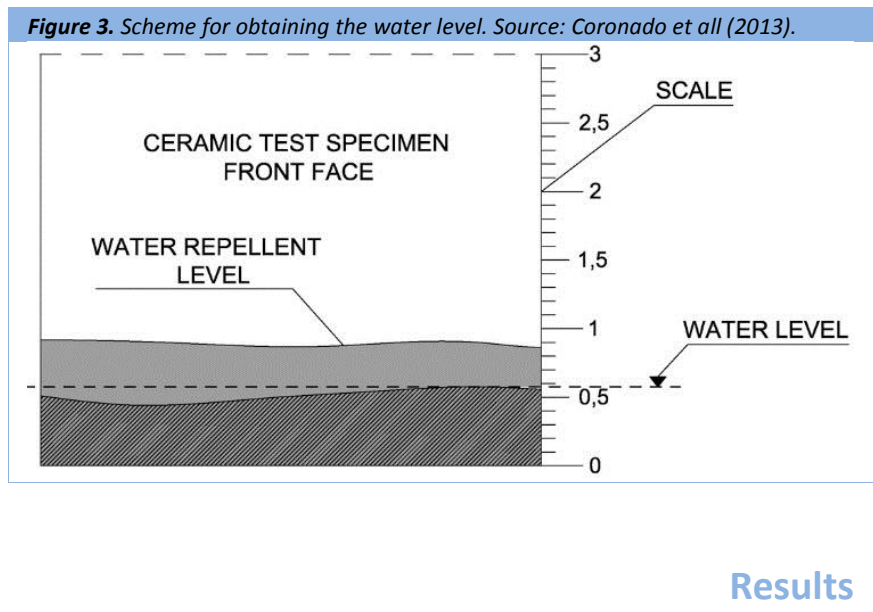

In tables 2 and 3 are shown as a manner of example the tables of the results obtained in the ceramics called $\mathrm{HO}$ (not waterproofed ceramic) and $\mathrm{H} 1 \mathrm{~B}$ and $\mathrm{H} 1 \mathrm{I}$, ceramic 1 waterproofing with $\mathrm{H} 1$ siliconates through brush and immersion respectively. The results of other waterproofed ceramics with different types of water repellents ( $\mathrm{H} 2 \mathrm{~B}$ and $\mathrm{H} 2 \mathrm{I}$, ceramic No. 2 waterproofed with $\mathrm{H} 2$ silanes by brush and immersion respectively, $\mathrm{H} 3 \mathrm{~B}$ and $\mathrm{H} 3 \mathrm{I}$, ceramic No. 3 waterproofed with $\mathrm{H} 3$ oligomeric siloxanes by brush and immersion respectively, $\mathrm{H} 4 \mathrm{~B}$ and $\mathrm{H} 4 \mathrm{i}$, ceramic No. 4 waterproof with $\mathrm{H} 4$ polymeric siloxanes by brush and immersion respectively, $\mathrm{H} 5 \mathrm{~B}$ and $\mathrm{H} 5 \mathrm{i}$, ceramic No. 5 waterproofed with $\mathrm{H} 5$ fluorinated resin by brush and immersion respectively $\mathrm{H} 6 \mathrm{~B}$ and $\mathrm{H} 6 \mathrm{I}$, number 6 ceramic waterproofed with $\mathrm{H} 6$ silanes / siloxanes by brush and immersion respectively) are shown graphically for comparison in Figures 4, 5 and 6. 


\begin{tabular}{|c|c|c|c|c|c|}
\hline \multirow[b]{2}{*}{$\begin{array}{l}\text { TIME } \\
\text { (min) }\end{array}$} & \multicolumn{5}{|c|}{ CERAMIC HO } \\
\hline & $\begin{array}{l}\text { WEIGHT } \\
\text { (g) }\end{array}$ & $\begin{array}{l}\% \text { \%o } \\
\text { WEIGHT } \\
\text { INCREASE }\end{array}$ & $\begin{array}{l}\text { ABSORPTION } \\
\text { RATIO } \\
\text { (Kg/m2xmin) }\end{array}$ & $\begin{array}{l}\text { WATER } \\
\text { LEVEL } \\
(\mathrm{mm}) \\
\end{array}$ & $\begin{array}{l}\% \quad \text { LEVEL } \\
\text { INCREASE }\end{array}$ \\
\hline 0 & 1427,64 & & & 2,50 & \\
\hline 1 & 1429,57 & 1,35 & 356,42 & 8,70 & 248,00 \\
\hline 2 & 1430,45 & 1,97 & 259,46 & 10,70 & 22,99 \\
\hline 5 & 1432,21 & 3,20 & 168,79 & 11,50 & 7,48 \\
\hline 10 & 1433,67 & 4,22 & 111,36 & 12,00 & 4,35 \\
\hline 15 & 1435,04 & 5,18 & 91,10 & 12,90 & 7,50 \\
\hline 20 & 1435,91 & 5,79 & 76,36 & 13,40 & 3,88 \\
\hline 25 & 1436,78 & 6,40 & 67,52 & 14,10 & 5,22 \\
\hline 30 & 1437,74 & 7,07 & 62,17 & 14,10 & 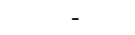 \\
\hline
\end{tabular}

In Figure 4, it is shown the comparative values of weight gain in relation to the time, from each waterproofed individual ceramics with different products, and through both water repelling methods (brush and immersion). The value of $\mathrm{HO}$ ceramics without being waterproofed in minute 1 is 1.35 and in minute 30 are 7.07. These values are not reflected in Figure 4 by the problem of scale involved.

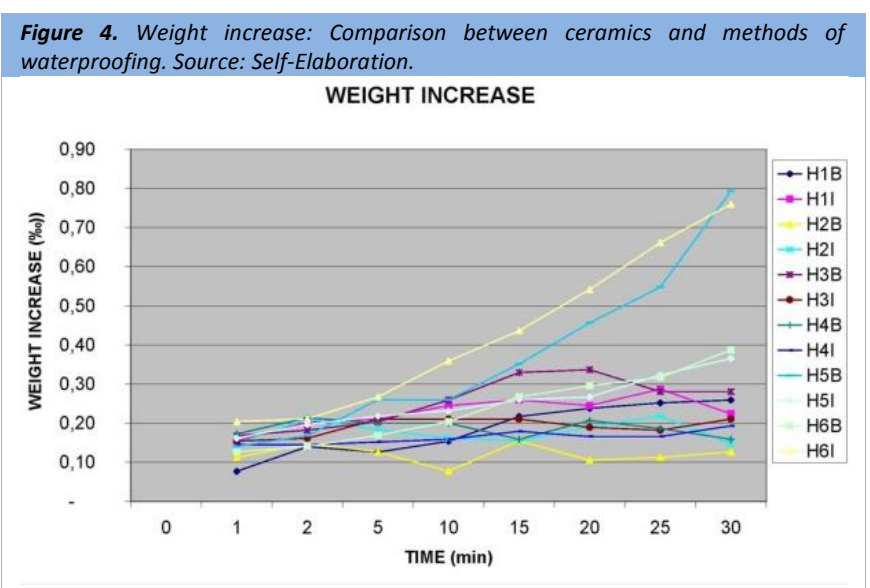

In Figure 5 are shown the comparative values of the absorption rate in relation to the time of each individual waterproofed ceramics with the distinct products and the two water repelling methods (brush and immersion). The value of $\mathrm{HO}$ ceramics without waterproofing in minute 1 is 356.42 and in minute 30 are 62.17 . These values are not reflected in Figure 5 by the problem of scale involved.

\begin{tabular}{|c|c|c|c|c|c|}
\hline \multirow[b]{2}{*}{$\begin{array}{l}\text { TIME } \\
(\min )\end{array}$} & \multicolumn{5}{|c|}{ CERAMIC 1 H1B } \\
\hline & $\begin{array}{l}\text { WEIGHT } \\
\text { (g) }\end{array}$ & $\begin{array}{l}\text { \% WEIGHT } \\
\text { INCREASE }\end{array}$ & $\begin{array}{l}\text { ABSORPTION } \\
\text { RATIO } \\
\text { (Kg/m2xmin) }\end{array}$ & $\begin{array}{l}\text { WATER } \\
\text { LEVEL } \\
(\mathrm{mm}) \\
\end{array}$ & $\begin{array}{lr}\% & \text { LEVEL } \\
\text { INCREASE }\end{array}$ \\
\hline 0 & $1.428,25$ & & & 2,50 & \\
\hline 1 & $1.428,36$ & 0,08 & 20,31 & 3,00 & 20,00 \\
\hline 2 & $1.428,45$ & 0,14 & 18,47 & 3,00 & - \\
\hline 5 & $1.428,43$ & 0,13 & 6,65 & 3,00 & - \\
\hline 10 & $1.428,47$ & 0,15 & 4,06 & 3,00 & - \\
\hline 15 & $1.428,56$ & 0,22 & 3,82 & 3,00 & - \\
\hline 20 & $1.428,59$ & 0,24 & 3,14 & 3,00 & - \\
\hline 25 & $1.428,61$ & 0,25 & 2,66 & 3,00 & - \\
\hline 30 & $1.428,62$ & 0,26 & 2,28 & 3,00 & - \\
\hline \multirow[b]{2}{*}{$\begin{array}{l}\text { TIME } \\
\text { (min) }\end{array}$} & \multicolumn{5}{|c|}{ CERAMIC 1 H1I } \\
\hline & $\begin{array}{l}\text { WEIGHT } \\
\text { (g) }\end{array}$ & $\begin{array}{l}\text { \% WEIGHT } \\
\text { INCREASE }\end{array}$ & $\begin{array}{l}\text { ABSORPTION } \\
\text { RATIO } \\
\text { (Kg/m2xmin) } \\
\end{array}$ & $\begin{array}{l}\text { WATER } \\
\text { LEVEL } \\
(\mathrm{mm})\end{array}$ & $\begin{array}{lr}\% & \text { LEVEL } \\
\text { INCREASE }\end{array}$ \\
\hline 0 & $1.428,10$ & & & 2,50 & \\
\hline 1 & $1.428,32$ & 0,15 & 40,63 & 4,80 & 92,00 \\
\hline 2 & $1.428,39$ & 0,20 & 26,78 & 5,00 & 4,17 \\
\hline 5 & $1.428,40$ & 0,21 & 11,08 & 5,90 & 18,00 \\
\hline 10 & $1.428,45$ & 0,25 & 6,46 & 6,00 & 1,69 \\
\hline 15 & $1.428,47$ & 0,26 & 4,56 & 6,10 & 1,67 \\
\hline 20 & $1.428,45$ & 0,25 & 3,23 & 6,20 & 1,64 \\
\hline 25 & $1.428,51$ & 0,29 & 3,03 & 6,30 & 1,61 \\
\hline 30 & $1.428,42$ & 0,22 & 1,97 & 6,30 & - \\
\hline
\end{tabular}

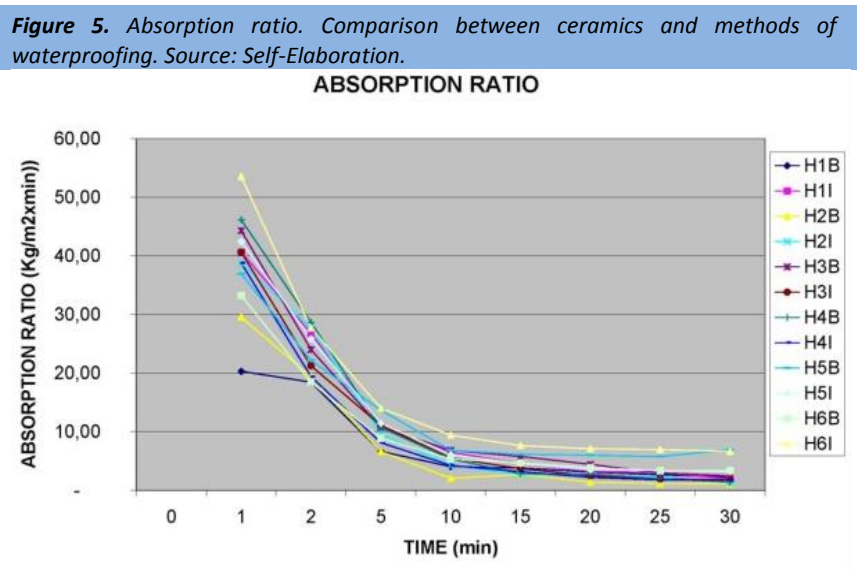


Figure 6 shows the comparative values of the surface water level in relation to the time of each individual waterproofed ceramic with the different products and by the two water repelling methods (brush and immersion). The value of $\mathrm{HO}$ ceramics without waterproofing in minute 1 is corresponding to 8.70 and in minute 30 it is 14.10 . These values are not reflected in Figure 6 by the problem of scale involved.

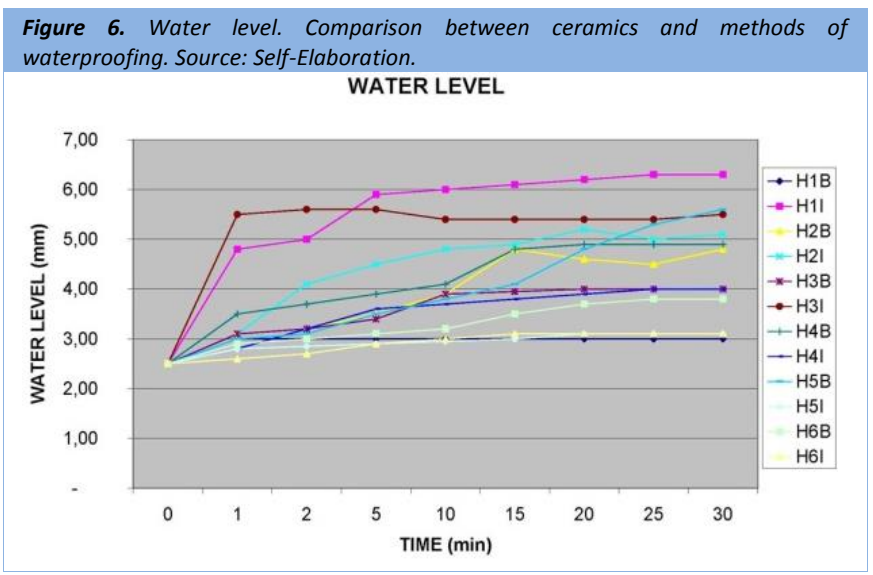

Discussion

All water repellents produce a significant modification in the variation parameters of weight, absorption rate and in the level of water measured superficially, concerning to the sample without water repelling, although they can establish differences between the of repellent type used and the application method.

Weight variation: Regardless of the method used for its application, we note that all water repellents reduce the variation in weight of the ceramic in relation with the ceramic without water repelling $(\mathrm{HO})$. In the minute 1 , the repellent which produces less weight gain is the $\mathrm{H} 1 \mathrm{~B}$, siliconate applied by brush, reducing $1.35(\mathrm{HO})$ to 0.08 , being the $\mathrm{H} 6 \mathrm{I}$, Silanes/siloxanes applied by immersion, which produces greater weight gain with 0.20 . From minute 5 , the $\mathrm{H} 2 \mathrm{~B}$ repellent, silanes applied with brush produces less weight gain. In the minute 5 it reduces from $3.20(\mathrm{HO})$ to 0.13 and in the minute 30 from 7.07 (HO) to 0.13 . In the minute 30 , the $\mathrm{H} 5 \mathrm{~B}$ repellent produces greater weight gain with a value of 0.79 .

Absorption ratio: All water repellents regardless of the method used for its application reduce the rate of absorption of the ceramic with regard to the one without water-repellent (HO). In the minute 1 , the repellent that most reduces the rate of absorption is $\mathrm{H} 1 \mathrm{~B}$, siliconates applied by brush, passing from $356,42(\mathrm{HO})$ to 20.31 . The one that least reduces it is the $\mathrm{H6I}$, Silanes/siloxanes applied by immersion with a value of 53,35 . In the minute 30 , the repellent that most reduces the rate of absorption is $\mathrm{H} 2 \mathrm{~B}$, silanes applied using brush, passing from $62,67(\mathrm{HO})$ to 1.11 . The one that least reduces it is $\mathrm{H} 5 \mathrm{~B}$, fluoridated resin applied by brush with a value of 6.96 .
Superficial water level: All water repellents, regardless of the method used for its application, reduce the superficial water level of the ceramic with regard to the one without waterrepellent (HO). In the 1 minute, the repellent showing a lower water level is $\mathrm{H6I}$, silanes/siloxanes applied by immersion, passing from a value of $8.70(\mathrm{HO})$ to 2.60 . The $\mathrm{H} 3 \mathrm{~L}$ repellent has the highest level of water at this moment with a value of 5.50. In the minute 30 , the $\mathrm{H} 1 \mathrm{~B}$ is the one that reduces the most the level of water, siliconates applied with brush, with a value of 3.00 (HO with value of 14.10). The $\mathrm{H} 1 \mathrm{l}$ produces less reduction with a value of 6.30 .

The results are analyzed in function of the repellent applied.

Repellent $\mathrm{H} 1$ siliconates: Applying siliconates by brush, we get in minute 1 less weight gain, lower absorption rate and lower level increase. In all measured times the result is the same as in the minute 1 , except at the rate of absorption in minute 30 which correspond to the water-repellence by immersion where the result is lower. According to the results presented for the $\mathrm{H} 1$ repellent siliconates, the brush application method produces a lower variation of weigh, lower absorption rate and lower level of superficial water.

Repellent $\mathrm{H} 2$ Silanes: The method of application by brush of the water repellent $\mathrm{H} 2$ Silanes produces a lower weight variation, a lower absorption rate and a lower superficial water level at all measured times.

Repellent $\mathrm{H} 3$ Oligomeric siloxanes: With respect to weight variation it is noticeable that from minute 1 to 5 , the method of application of water repellent by brush, H3 produces lower results. From minute 5 to 30 the immersion method shows less variation in weight. As for the absorption rate, the immersion method shows lower results, except in minute 5 in which it is slightly higher than the brush method. The superficial water level is lower in ceramic under the water repellent by the brush method.

Repellent H4 Polymeric siloxanes: The application method by immersion of the $\mathrm{H} 4$ repellent, polymeric siloxanes, generally produces lower weight variation, lower absorption rate and lower level of superficial water at all measured times, except in minute 15 and 30 in variation of weight, and rate of absorption in minute 15 , where the results of water-repellence by brush are slightly lower.

Repellent H5 Fluorinated resin: The application by immersion of the $\mathrm{H} 5$, fluoridated resin, produces lower weight variation, lower absorption rate and lower level of superficial water at all measured times, except in minute 1 and 2 in weight variation, and absorption rate where the results, of water-repellence applied by brush, are slightly inferior.

Repellent $\mathrm{H} 6$ Silanes / siloxanes: We note that the method of application of water repellent $\mathrm{H} 6$ silanes / siloxanes by brush produces less variation in weight and lower rate of absorption. At the level of surface water, the immersion method produces slightly lower results than those obtained by brush. 
The surface of the ceramic facade treated with water repellent products, regardless of the method used for its application (brush or immersion), reduce the weight variation parameters, absorption rate and the water level superficially measured of the ceramic that had not been waterproofed $(\mathrm{HO})$. The variation of these parameters is determined by the type of waterproofing product and the method used for the waterproofing process.

\section{About the waterproofing method}

In water repellent products of siliconate composition $\mathrm{H} 1$, the method of application by brush produces fewer variations in weight, lower absorption rate and lower level of surface water. In water repellent products of silane composition $\mathrm{H} 2$, the method of application by brush produces fewer variations in weight, lower absorption rate and lower level of surface water. In the water repellent products of oligomeric siloxane composition $\mathrm{H} 3$, the method of application by immersion produces fewer variations in weight from 5 minutes and makes slower the rate of absorption. The method of application by brush produces lower level of surface water. In the water repellent products of polymeric siloxane composition $\mathrm{H} 4$, the method of application by immersion produces overall lower weight variation, slower rate of absorption and lower surface water level. In water repellent products composed by resin fluorinated $\mathrm{H} 5$, the application method by immersion generally produces a lower weight variation, slower rate of absorption and lower level of water surface.

In water repellent products composed by silane/siloxane $\mathrm{H} 6$, the method of application by brush generally causes less variation in weight and rate of absorption. The application method by immersion produces slightly lower results in the level of water surface. Regarding the method of waterproofing application, this result allows us to suggest that for porous ceramic pieces with similar characteristics tested in this article, it is convenient to make the following choice:

- Waterproofing method by brush if the applied product is composed by siliconates ( $\mathrm{H} 1 \mathrm{~B})$ and silanes ( $\mathrm{H} 2 \mathrm{~B})$, as it is the method that produces greater modification of the following parameters: weight variation, absorption rate and level of water surface and composed by silane/siloxanes (H6B), as this causes the greatest modification in the parameters of weight variation and rate of absorption.

- Waterproofing method by immersion if the applied product is composed by polymeric siloxane $(\mathrm{H} 4)$ and fluorine resin (H51), as this is the method that produces the greatest change of the parameters of weight variation, rate of absorption and surface water level and sixolanos component of oligomeric ( $\mathrm{H} 31)$ because it produces greater change in the parameters of weight change (from $5 \mathrm{~min}$ ) and absorption rate.

\section{About the water repellent product}

All water repellents superficially applied to a porous ceramic material, reduce weight variation parameters, rate of absorption and surface water level regarding the base material which has not been waterproofed, regardless the method used for its application (brush or immersion).

Regarding the change in weight, water repellent composed by silane and applied with brush ( $\mathrm{H} 2 \mathrm{~B})$ is what produces less variation in weight for 5 minutes, with a decrease in the minute 30 concerning the base sample of $98.16 \%$.

Regarding the rate of absorption, water repellent silane component applied with brush $(\mathrm{H} 2 \mathrm{~B})$ is what produces the lowest absorption rate for 5 minutes, decreasing in the minute 30 concerning the base sample of $98.21 \%$.

Regarding the level of surface water, water repellent silane/siloxane component applied by immersion (H6B) is reaching the lowest level with 10 minutes and the siliconates component applied with brush ( $\mathrm{H} 1 \mathrm{~B})$ is the reaching lower level between the minute 10 to the minute 30 . The variation between these two is very minimal reducing both the level of surface water regarding the base sample in the minute 30 in approximately $78 \%$.

Concerning to the water repellent product, this result allows us to suggest that for the hydrophobicity of porous ceramic pieces with similar characteristics to the one analyzed in this article, we recommend choosing repellent silane component ( $\mathrm{H} 2)$ applied with a brush since it corresponds to the product that produces optimal results in two of the three parameters studied. 


\section{References}

AENOR-CEN (2001) Asociación Española de Normalización. UNEEN 772-11:2001, Métodos de ensayo de piezas para fábrica de albañilería. Parte 11: Determinación de la absorción de agua por capilaridad de piezas para fábrica de albañilería, en hormigón, piedra natural y artificial, y de la tasa de absorción de agua inicial de las piezas de arcilla cocida para fábrica de albañilería. AENOR: Madrid, Spain.

Chávez V, J. A. \& Álvarez R, O. (2005). Metodología para el diagnóstico y restauración de edificaciones. Revista de la construcción. 4(2), 47-54.

Coronado M, J. A. (2012) Influencia de los productos hidrofugantes en las propiedades superficiales de las cerámicas porosas utilizadas en cerramientos exteriores cara vista, PhD Thesis in Architecture, Polytechnic University of Madrid [Thesis in Spanish]

Coronado M, J. A. \& García S, A. (2011). La influencia de los productos hidrofugantes en las modificaciones cromáticas del ladrillo cerámico. Materiales de construcción. 61(304), 597-611. doi:10.3989/mc.2011.57810.

Coronado M, J. A.; Garcia S, A., and Padial M, J. F. (2013). La influencia de los productos hidrofugantes en la succión del ladrillo cerámico cara vista. Boletín de la sociedad española de cerámica y vidrio. 52(4), XV-XVIII.

Coronado M, J. A.; Garcia S, A., and Padial Molina J. F. (2013). Análisis mediante microscopio electrónico de barrido de la succión del ladrillo visto de fabricación extrusionada hidrofugado. Axioma. 2(11), 27-33.

Doehne, E. \& Price, C. A. (2010). Putting it right: Preventive and remedial treatments. Getty Conservations Institute (Eds.), Stone Conservation. An Overview of Current Research, 27-48. Los Angeles: Getty Publications.

Fort, R. (2007) Polímeros sintéticos para la conservación de materiales pétreos. In: Ciencia, Tecnología y Sociedad para una conservación sostenible del patrimonio pétreo. Pérez-Monserrat, E.M., Gómez-Heras, M. Álvarez de Buergo, M., Fort, R. (eds). Dpto. Publicaciones Universidad Popular José Hierro, San Sebastián de los Reyes. 71-82. ISBN: 84-95710-41-2

García S, A. (2001). Los Plásticos en la Construcción I y II. Madrid. Cuadernos del Instituto Juan Herrera, Escuela Técnica Superior de Arquitectura.

Wacker-chemie Gmbh, (1973). Procedimiento para hidrofugar superficies de materiales de construcción. Invention Patent.

Young, M. E., Murray, M. \& Cordiner, P. (1999). Stone consolidants and chemical treatments in Scotland. Edinburg: Historic Scotland. 